Table 1. The arsenic concentrations of water before and after filtered through Mesopaper.

\begin{tabular}{|c|c|c|c|c|c|c|}
\hline & \multicolumn{2}{|c|}{$\begin{array}{l}\text { Gansu } \\
\left(\mu \mathrm{g} \mathrm{L}^{-1}\right)\end{array}$} & \multicolumn{2}{|c|}{$\begin{array}{l}\text { Innner } \\
\text { Mongolia } \\
\left(\mu \mathrm{g} \mathrm{L}^{-1}\right)\end{array}$} & \multicolumn{2}{|c|}{$\begin{array}{l}\text { Hunan } \\
\left(\mu \mathrm{g} \mathrm{L}^{-1}\right)\end{array}$} \\
\hline & $\begin{array}{l}\text { One } \\
\text { layer }\end{array}$ & $\begin{array}{l}\text { Two } \\
\text { layer }\end{array}$ & $\begin{array}{l}\text { One } \\
\text { layer }\end{array}$ & $\begin{array}{l}\text { Two } \\
\text { layer }\end{array}$ & $\begin{array}{l}\text { One } \\
\text { layer }\end{array}$ & $\begin{array}{l}\text { Two } \\
\text { layer }\end{array}$ \\
\hline Startup & 729 & 729 & 1658 & 1658 & 86580 & 86580 \\
\hline $0.2 \mathrm{~L}$ & 3 & 0 & 26 & 0 & 47849 & 1125 \\
\hline $0.4 \mathrm{~L}$ & 5 & 0 & 82 & 5 & 79454 & 27277 \\
\hline $0.6 \mathrm{~L}$ & 13 & 0 & 557 & 38 & 80745 & 53796 \\
\hline $0.8 \mathrm{~L}$ & 21 & 0 & 685 & 80 & 77566 & 65696 \\
\hline $1.0 \mathrm{~L}$ & 33 & 0 & 843 & 129 & 82520 & 68370 \\
\hline
\end{tabular}

And then, 1 liter (L) water sample was prepared and poured through the Mesopaper, with $0.2 \mathrm{~L}$ every time. The arsenic concentrations were determined at accumulated filtration volume of $0.2 \mathrm{~L}, 0.4 \mathrm{~L}, 0.6 \mathrm{~L}, 0.8 \mathrm{~L}$ and $1 \mathrm{~L}$. In this study, we tested the arsenic removal efficiency of one layer and two layers of Mesopaper, respectively.

\subsection{Arsenic leaching experiment}

The major activated media for Mesopaper to remove arsenic is the nano-scale powder. And then, we directly tested the arsenic leaching rate of nano-scale powder equipped with enough arsenic. $2 \mathrm{~g}$ nano-scale powder that had been adsorbed nearly $3.56 \mathrm{mg}$ arsenic were weighted and putted into $100 \mathrm{~mL}$ solutions with different $\mathrm{pH}$ values of $3,5,7$ and 9 , respectively. After stirring for 5 minutes, the supernatant liquid was extracted to determination of arsenic concentrations.

\subsection{Arsenic determination}

The arsenic concentrations of all water samples in this report were measured using hydride generation-atomic fluorescence spectroscopy (HF-AFS).

\section{RESULTS AND DISCUSSION}

\subsection{Arsenic removal efficiency}

Table 1 displays the removal effect of As by Mesopaper. It was obvious that the arsenic concentrations of the three samples were all significantly decreased after filter through one layer and two layers of Mesopaper. In Gansu samples, for example, more than $90 \%$ arsenic was adsorbed by one-layer Mesopaper and the final arsenic concentrations was below $10 \mu \mathrm{g} \mathrm{L}^{-1}$ at the sampling point of $0.2 \mathrm{~L}$ and $0.4 \mathrm{~L}$. In addition, our findings have also suggested that the arsenic removal efficiency for two layers of Mesopaper was
Table 2. The arsenic leaching rate of nano-scale powder.

\begin{tabular}{lll}
\hline $\mathrm{pH}$ values & $\begin{array}{l}\text { Arsenic concentration } \\
\left(\mu \mathrm{g} \mathrm{L}^{-1}\right)\end{array}$ & $\begin{array}{l}\text { Arsenic leaching } \\
\text { rate }(\%)\end{array}$ \\
\hline 3 & 150 & 0.42 \\
5 & 10 & 0.03 \\
7 & 7.5 & 0.02 \\
9 & 10 & 0.03 \\
\hline
\end{tabular}

Note: The arsenic leaching rate were calculated as [(arsenic concentration * $100 \mathrm{~mL}) / 3.56 \mathrm{mg}]$.

significantly higher than that shown in one layer. We supposed that the better efficiency might be associated with the relatively much more nano-scale powder and large surface area presented in two layers of Mesopaper. Together, all above findings have suggested that the Mesopaper has highly effective in treatment of field arsenic-contaminated water.

\subsection{Arsenic leaching rate}

As it listed in Table 2, the arsenic leaching rate in solutions with $\mathrm{pH}$ values of $3,5,7$ and 9 were all relatively low. The findings give evidence on that the nano-scale powder used in Mesopaper has no secondary arsenic pollution.

\section{CONCLUSIONS}

The Mesopaper has high effectiveness in treatment of field arsenic-contaminated water and without secondary arsenic pollution.

\section{ACKNOWLEDGEMENTS}

This work was sponsored by National Natural Science Foundation of China (Code number: 81703172).

\section{REFERENCES}

Naujokas, M.F., Anderson, B., Ahsan, H., Aposhian, H.V., Graziano, J.H., Thompson, C. \& Suk, W.A. 2013. The broad scope of health effects from chronic arsenic exposure: update on a worldwide public health problem. Environ. Health Perspect. 121(3): 295.

Singh, R., Singh, S., Parihar, P., Singh, V.P. \& Prasad, S.M. 2015. Arsenic contamination, consequences and remediation techniques: a review. Ecotoxicol. Environ. Saf. 112: 247-270.

Tang, J., Liao, Y., Yang, Z., Chai, L. \& Yang, W. 2016. Characterization of arsenic serious-contaminated soils from Shimen realgar mine area, the Asian largest realgar deposit in China. J. Soils Sediments 16(5): 1519-1528. 


\title{
Decrease of arsenic in water from the Pampean plain (Argentina) by calcium salts addition
}

\author{
L. Cacciabue ${ }^{1}$, S. Dietrich ${ }^{1}$, P.A. Weinzettel ${ }^{1}$, S. Bea ${ }^{1}$, L. Sierra ${ }^{1}$ \& C. Ayora ${ }^{2}$ \\ ${ }^{1}$ Instituto de Hidrología de Llanuras "Dr. Eduardo J. Usunoff”" (IHLLA), Azul, Buenos Aires, Argentina \\ ${ }^{2}$ Instituto de Diagnóstico Ambiental y Estudios del Agua (IDAEA-CSIC), Barcelona, Spain
}

\begin{abstract}
Arsenic (As) presence in groundwater from Argentinean Pampean plain is favored by high $\mathrm{pH}$ and $\mathrm{Na}-\mathrm{HCO}_{3}^{-}$type waters. Our hypothesis was that by adding $\mathrm{Ca}$ to the aquifer system, $\mathrm{pH}$ could decrease due to calcite precipitation and As may be retained in solid phase (sediments). Batch experiments were performed on natural sediments in contact with a Na- $\mathrm{HCO}_{3}^{-}$solution, where $\mathrm{CaSO}_{4}$ or $\mathrm{CaCl}_{2}$ were added. Ca salts addition decreased down to 0.3 points of $\mathrm{pH}$ solution and as a result, As concentration in solution decreased. Two mechanisms are proposed. One is that a small decrease in $\mathrm{pH}$ enhanced As adsorption on Fe oxides. The second is that calcite precipitated and could trap As inside its structure.
\end{abstract}

\section{INTRODUCTION}

High arsenic (As) groundwater concentrations remain a critical concern in the Pampean plain of Argentina (Nicolli et al., 2012). Groundwater from the Pampean aquifer presents a $\mathrm{Na}-\mathrm{HCO}_{3}$ hydrochemical signature and $\mathrm{pH}$ values higher than 7.5 . Stratigraphic sequence in the area is composed of loess sediments which are interbedded with numerous petrocalcic layers (known as calcrete or tosca) indicating semi-arid paleoclimatic conditions (Zárate \& Tripaldi, 2012). Natural occurrence of high As-bearing carbonates was reported in the literatures (Alexandratos et al., 2007; Winkel et al., 2013), suggesting that As retention by calcite precipitation could be a natural process in the groundwater systems of the Pampean plain. The aim of this work is two-fold: (1) to assess a potential As removal treatment based on the addition of $\mathrm{Ca}$ salts that induce the calcite precipitation, $\mathrm{pH}$ decrease, and As retention; (2) to propose the aforementioned mechanisms as the ones responsible for the high As concentrations that were measured in some tosca layers.

\section{METHODS/EXPERIMENTAL}

In order to verify the effectiveness of the proposed geochemical mechanisms, the experiment was simulated with the model PHREEQC (Parkhurst, 1995), by adding $\mathrm{Ca}$ salts to a $\mathrm{Na}-\mathrm{HCO}_{3}^{-}$initial solution. This simulation allowed calculating the $\mathrm{Ca}$ mass needed to produce a decreasing of $\mathrm{pH}$ from 9 to 7 .

Prior to batch experiments, a synthetic Na$\mathrm{HCO}_{3}^{-}$solution was prepared with miliQ water and $\mathrm{NaCl}$ (EMSURE), $\mathrm{MgCl}_{2}$ (Sigma-Aldrich) $\mathrm{NaHCO}_{3}$ (Merck) and $\mathrm{CaSO}_{4}$ (Merck) salts. Solution $\mathrm{pH}$ was adjusted with $\mathrm{KOH}$.
Table 1. Textural and mineralogical characteristics of selected samples.

\begin{tabular}{llll}
\hline Sample & Minerals & Texture & Type \\
\hline M12 & $\begin{array}{l}\text { Calcite, quartz, Na } \\
\text { rich anorthite, }\end{array}$ & $\begin{array}{l}\text { Silt 54\%, } \\
\text { Sand 26\%, }\end{array}$ & Tosca \\
& Na-montmorillonite & Clay 20\% & \\
M22 & Quartz, calcite, Ca & Sand 55\%, & Sandy \\
& rich albite, & Silt 35\%, & loess \\
& Na-montmorillonite & Clay 10\% & \\
M41 & Quartz, Na rich & Silt 58\%, & Silty \\
& anorthite, & Sand 27\%, & loess \\
& Na-montmorillonite & Clay 16\% & \\
\hline
\end{tabular}

Sediment samples were obtained from a $70 \mathrm{~m}$ deep borehole located in Tres Arroyos city, Buenos Aires province, Argentina (Sierra et al., 2016). Selected samples correspond to 12, 22 and $41 \mathrm{~m}$ depth (M12, M22 and M41, respectively). Main features of selected samples are shown in Table 1. Sediment samples showed similar composition, although M41 is the only sample where calcite was not observed (Table 1). Previous studies showed that samples M12 and M41 are of silt grain size whereas M22 is a fine sand (Sierra et al., 2016).

Five suspensions were prepared with the following solids: M12, M22, M41, M41Fe (1\% of ferrihydrite added) and MQz (pure quartz sand, considered as a blank). Six $50 \mathrm{~mL}$-tubes were filled with $2 \mathrm{~g}$ of each sample, which were washed with MiliQ-water, centrifuged and dried.

Then, $10 \mathrm{~mL}$ of $\mathrm{NaHCO}_{3}$ synthetic solution with $500 \mu \mathrm{g} \mathrm{L}^{-1}$ of As were added to each tube. After $24 \mathrm{~h}$ shaking, 3 and $7 \mathrm{mmol}$ of $\mathrm{CaSO}_{4}$ and $\mathrm{CaCl}_{2}$ salts were added, respectively. After $48 \mathrm{~h}$ shaking, final $\mathrm{pH}$ was measured. Samples were centrifuged at $4500 \mathrm{rpm}$ 


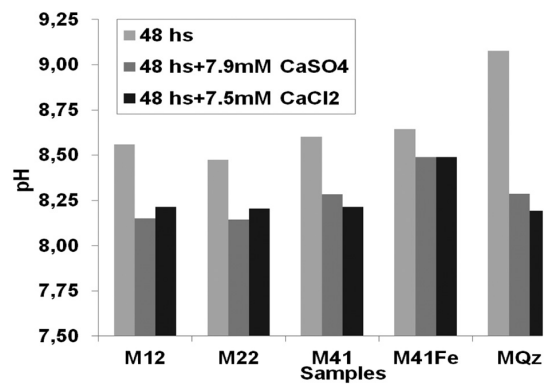

Figure 1. $\mathrm{pH}$ variations on samples through the experiments.

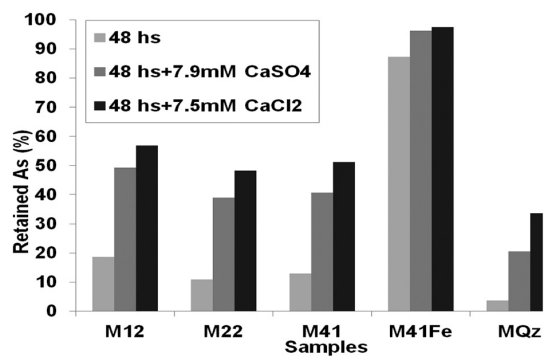

Figure 2. Retained As percentages on samples through the experiments.

during $15 \mathrm{~min}$ and filtered with nylon membrane of $0.2 \mu \mathrm{m}$ pore. Aliquots of $5 \mathrm{~mL}$ were collected from each tube and acidified with $\mathrm{HNO}_{3} \quad 10 \%$. Arsenic concentrations were measured by inductively coupled plasma mass spectrometry (ICP-MS). Chloride interference was verified with an As blank solution.

\section{RESULTS AND DISCUSSION}

PHREEQC calculations yielded a decrease from 9.1 to $7.1 \mathrm{pH}$ units in one liter of water by adding $7.9 \mathrm{mM}$ of $\mathrm{CaSO}_{4}$ or $7.5 \mathrm{mM}$ of $\mathrm{CaCl}_{2}$.

After $48 \mathrm{~h}$, samples equilibrated with $\mathrm{Na}-\mathrm{HCO}_{3}$ solution at an approximate $\mathrm{pH}$ of 8.5 without salts addition (Fig. 1). This is because carbonates, which are present in almost all samples, have buffer properties. In this sense, quartz sample (MQz) had no initial change in $\mathrm{pH}$ due to its low reactivity with solution. After salts addition, $\mathrm{pH}$ showed a slight decrease, with a maximum of 0.3 units, compared with that obtained from PHREEQC.

Regarding As retention in absence of Ca salts, samples M12, M22 and M41 retained 13, 11 and 19\% of total initial As, respectively (Fig. 2). Ca addition enhanced the As retention in all samples, which increased to 51,48 and $57 \%$, respectively.

The addition of $\mathrm{CaCl}_{2}$ showed slightly more efficiency than $\mathrm{CaSO}_{4}$ in the As retention. Sample M41Fe achieved $87 \%$ of As retention in the absence of Ca salts due to the presence of ferrihydrite, which increases the specific surface area practically adsorbing the initial mass of As (Dixit \& Hering, 2003). The Ca salts addition in this sample raised the As retention in a $10 \%$ only. Sample MQz denoted an As retention of $30 \%$ by adding $\mathrm{Ca}$ salts, suggesting that the precipitated calcite could retain As into its structure or may adsorbed on its surface.

\section{CONCLUSIONS}

Ca salts addition to a synthetic water sample, similar to Pampean groundwaters, generated only a slight $\mathrm{pH}$ decrease. However, As retention on solid samples increased up to the double of its retaining capacity.

Although a decrease in $\mathrm{pH}$ favored As sorption on Fe oxides, calcite precipitation retained almost $30 \%$ of total As.

Arsenic uptake by calcite may be explained by entering calcite structure or by adsorbing on calcite surface.

\section{ACKNOWLEDGEMENTS}

This work was funded by the research project PID075/2012 titled "Spatial-Temporal evolution of arsenic in groundwater of Argentina Republic". Authors gratefully acknowledge the cooperation of Institut de Diagnosi Ambiental i Estudis de l'Aigua (Barcelona) to provide working place and chemical analyses. Special thanks to Dr. Ester Torres who had suggested optimization procedures for the experiments.

\section{REFERENCES}

Alexandratos, V.G., Elzinga, E.J. \& Reeder, R.J. 2007. Arsenate uptake by calcite: macroscopic and spectroscopic characterization of adsorption and incorporation mechanisms. Geochim. Cosmochim. Acta 71(17): 4172-4187.

Dixit, S. \& Hering, J.G.2003. Comparison of arsenic (V) and arsenic (III) sorption onto iron oxide minerals: implications for arsenic mobility. Environ Sci. Technol. 37(18): 4182-4189.

Nicolli, H.B., Bundschuh, J., Blanco, M.D.C., Tujchneider, O.C., Panarello, H.O., Dapena, C. \& Rusansky, J.E. 2012. Arsenic and associated trace-elements in groundwater from the Chaco-Pampean plain, Argentina: results from 100 years of research. Sci. Total Environ. 429: 36-56.

Parkhurst, D.L. 1995. User's guide to PHREEQC-a computer program for speciation, reaction-path, advective transport and inverse geochemical calculations. U.S.G.S. Water Resources Investigations Report. 95-4227.

Sierra, L., Cacciabue, L., Dietrich, S., Weinzettel, P.A. \& Bea, S.A. 2016. Arsenic in groundwater and sediments in a loessic aquifer, Argentina. In: Arsenic Research and Global Sustainability: Proceedings of the $6^{\circ}$ International Congress on Arsenic in the Environment. Stockholm, Sweden.

Winkel, L.H.E., Casentini, B., Bardelli, F., Voegelin, A., Nikolaidis, N.P. \& Charlet, L. 2013. Speciation of arsenic in Greek travertines: co-precipitation of arsenate with calcite. Geochim. Cosmochim. Acta 106: 99-110.

Zárate, M. \& Tripaldi, A. 2012. The aeolian system of central Argentina. Aeolian Res. 3(4): 401-417. 